\title{
Clinical and histopathological characteristics of ocular surface squamous neoplasia: Evidence from a tertiary eye care center, northwest Ethiopia
}

\author{
Tesfalem Hagos Gebremariam ${ }^{1}$, Yared Assefa Wolde ${ }^{*}$, Destaye Shiferaw Alemu², Bewket Abebe Alemu ${ }^{3}$ and Kebrom Legesse ${ }^{2}$ \\ ${ }^{1}$ Department of Ophthalmology, College of Medicine and Health Sciences, University of Gondar, Gondar, Amhara National Regional State, Ethiopia \\ ${ }^{2}$ Department of Optometry, College of Medicine and Health Sciences, University of Gondar, Gondar, Amhara National Regional State, Ethiopia \\ ${ }^{3}$ Department of Pathology, College of Medicine and Health Sciences, University of Gondar, Gondar, Amhara National Regional State, Ethiopia
}

\begin{abstract}
Background: Ocular surface squamous neoplasia is a spectrum of diseases encompassing from mild dysplasia to invasive squamous cell carcinoma of the ocular surface.

Patients and methods: A series of 50 cases with suspected ocular surface squamous neoplasia presenting to Gondar University Hospital Tertiary Eye Care and Training Center, Northwest Ethiopia from January 2015 to June 2016 were enrolled. Clinical parameters were documented through interviewer administered questionnaire and ocular examination. Excisional or incisional biopsy was done on suspected conjunctival lesions and sent for histopathology examination to an experienced pathologist. Statistical Packages for Social Sciences version 21 was used to analyze data.

Results: Mean age of the participants was 41.26 years (age range 18-75) and $72 \%$ of the cases were males. Majority of the participants were farmers (40\%). Human immunodeficiency virus (HIV) was positive in $22 \%$ of the participants. Leukoplakic appearance was the commonest (68\%) and nasal side of the conjunctiva was the commonest location of the lesions ( $72 \%)$. Feeding vessels were observed in $84 \%$ of the participants. Histopathological examination revealed ocular surface squamous neoplasia in $96 \%$ of the participants. Among these $36 \%$ had carcinoma in situ, $36 \%$ had invasive squamous cell carcinoma, $18 \%$ had conjunctival/corneal intraepithelial neoplasia and $10 \%$ had associated pterygium clinically and on histology as well.

Conclusion and recommendations: Almost all the clinically suspected OSSN lesions were actual OSSN in histology. Most of the ocular surface squamous neoplasia cases in the study were non-HIV positive young males and had the lesion on their nasal side of the globe. Despite the age of the patient and status of HIV infection it is good to subject suspected OSSN lesions for histopathological examination. Most of the patients were farmers and the role of other risk factors need to be considered and large-scale studies are recommended in Ethiopia and other African countries in the future.
\end{abstract}

\section{Introduction}

Ocular surface squamous neoplasia (OSSN) includes a spectrum of conjunctival/corneal mild dysplasia to carcinoma in situ to invasive squamous cell carcinoma that occurs mostly on the exposed part of the globe [1]. Prevalence of OSSN varies from 0.3-19 per million populations depending on the geographic location being more common in countries that are closer to the equator where excessive exposure to sunlight is more common [2-5].

Age of occurrence of OSSN is reported to be variable predominantly affecting older males in temperate climates and on the contrary in Sub - Saharan Africa it affects young males and females [6,7]. The incidence of OSSN in sub-Saharan countries is increasing and presents as an aggressive tumor affecting younger patients. This may be explained by high incidence of HIV, high incidence of exposure to human papilloma virus (HPV), and solar radiation exposure [8-10]. According to some reports, more than $50 \%$ of Sub-Saharan patients with OSSN have underlying Human Immunodeficiency Virus (HIV) infection and present with advanced disease [6]. Reports from temperate climates indicate advanced age and male gender are more associated with the diseases, however in East Africa OSSN is more associated with young age and female gender [3,6-9]. Though there are clinical signs commonly associated with malignancy of conjunctival lesions, these signs are also reported to be clinical signs of benign lesions as well [9].

Diagnosis of invasive Squamous Cell Carcinoma (SCC) by clinical examination alone is correct only in $30 \%$ of cases even by experienced clinicians $[1,11]$. Correct diagnosis mainly rests on the histopathological examination of the excised lesion which is the gold standard method. The drawback with this method is its unavailability in most eye clinics of Sub Saharan African countries and most lesions are surgically excised without histopathological examination $[12,13]$.

Published works regarding the clinical and histopathological characteristics of OSSN in Ethiopia and at the study area is not available except a report on pattern of ophthalmic lesions at histopathology centers [14]. The aim of this study was to describe the clinical and

${ }^{\star}$ Correspondence to: Yared Assefa Wolde, Department of Ophthalmology, College of Medicine and Health Sciences, University of Gondar, Gondar, Amhara National Regional State, Ethiopia, E-mail: assefabi2003@yahoo.com

Key words: histopathology, ocular surface squamous neoplasia, Gondar, Ethiopia

Received: September 14, 2018; Accepted: October 08, 2018; Published: October 12,2018 

Ethiopia

histopathological characteristics of OSSN at Gondar University Hospital tertiary eye care and training center.

\section{Patients and methods}

\section{Study design and period}

The study was clinicopathological evaluation of a series of clinically suspected OSSN cases from January 2015 - June 2016.

\section{Study area}

The study was conducted at Gondar University Hospital tertiary eye care and training center, which is found in Gondar City, Amhara region, Northwest Ethiopia. The study setting is located at a latitude and longitude of $12^{\circ} 36^{\prime} \mathrm{N} 37^{\circ} 28^{\prime} \mathrm{E}$ with an elevation of 2133 meters above sea level [15]. Gondar is located 730 kilometers from the national capital; Addis Ababa with a total population of 207,044. Gondar University Hospital tertiary eye care and training center is the only tertiary center in the region with a catchment population of 14 million. The tertiary center has 6 ophthalmologists, 21 optometrists, 3 ophthalmic nurses and one cataract surgeon. The center has a postgraduate training program in ophthalmology residency training that is provided for 4 years. The center has different subspecialty clinics among these is the anterior segment clinic where patients with OSSN are referred to.

All patients clinically suspected to have OSSN and had histopathological examination of excised conjunctival lesion were included while patients who were not volunteer to have the surgery and patients who had surgery but refused to have histopathological examination of excised lesions were excluded from the study.

\section{Definition used in the study}

Excisional biopsy with wide margin=excision of a lesion with 3-4 $\mathrm{mm}$ safety margin, Conjunctival intraepithelial neoplasia $(\mathrm{CIN})=$ partial involvement of the corneal/conjunctival epithelial layer by neoplastic cells, carcinoma insitu (CIS) =full thickness involvement of corneal $/$ conjunctival epithelium by neoplastic cells, invasive squamous cell carcinoma $=$ corneal/conjunctival basement membrane invasion by neoplastic cells.

\section{Variables of the study}

The outcome variable of the study was the presence of pathologically confirmed OSSN and the explanatory variables were age, occupation, sex, HIV infection status, pterygium, smoking, and history of eye trauma.

\section{Data collection procedure and instruments}

Clinical data was collected from patients with suspected OSSN and were evaluated by senior ophthalmologists and each clinical parameter was documented through an interviewer administered questionnaire by final year ophthalmology residents. Clinical parameters included are demographic data of patients, history of trauma, smoking, position of lesion, lesion size (with estimated clock hours), lesion feeding vessels, pigmentation, appearance of lesion (leukoplakic, gelatinous, papilliform, fungating mass, sessile), site of involvement, local or distant metastasis, presence of associated pterygium, recurrence of conjunctival lesion after excision and HIV status. Suspected small lesions underwent 3-4 millimeters safety margin excisional biopsy and alcohol epitheliectomy of the cornea. Incisional biopsy was done for larger lesions involving most of the ocular surface area or local metastasis to the orbit and eyelid by either an ophthalmologist or final year ophthalmic resident after written consent of the patients was found. Specimen was fixed in $10 \%$ buffered formalin and transported to a single experienced pathologist, department of pathology for histologic examination and results were filled under CIN, CIS and invasive SCC.

Data quality assurance: To assure the quality of data in the study, data collectors were supervised by principal investigator and senior ophthalmologists.

Data processing and analysis: Data was cleaned and analyzed with SPSS version 21. Tables, mean and proportion were used to describe the results.

Ethical considerations: Ethical clearance was obtained from the research ethical review committee of UOG. Verbal consent was taken from the participants prior to data collection and written consent was taken before doing surgery. The tenets of the Helsinki declaration of medical research were followed during the research process [16].

\section{Results}

\section{Socio-demographic characteristics of study participants}

A total of 50 participants were enrolled and among these $72 \%$ were males. The mean age of the patients was 41.26 year (age range18-75 year). Majority were farmers (40\%) followed by civil servants (28\%) and daily laborers (14\%) (Table 1).

\section{Clinical features of ocular surface squamous neoplasia}

Leukoplakic appearance was the commonest in $30(60 \%)$ participants followed by gelatinous in $6(12 \%)$, papilliform in $5(10 \%)$ and 4 cases (8\%) had large elevated fungating masses. Nasal (74\%) and temporal (18\%) sides of the globe were the commonest location of the lesion. The size of the majority of the OSSN ranges from 1-3 clock hours (74\%). Large feeder vessels occurred in 42 (84\%), dark pigmentation was seen in $6 \%, 22 \%$ of the participants were HIV positive. The size of conjunctival involvement in participants with SCC was 6 clock hours and beyond in $55.6 \%$ of the participants. Recurrence of previously excised lesion was observed in 6 (12\%) participants (Table 2).

\section{Histopathological diagnosis of suspected ocular surface neoplasia}

The histopathology results of all participants included in the study was reported by the examining pathologist and $6(12 \%)$ participants had CIN, 18 (36\%) had CIS, 18 (36\%) had SCC. Pterygium was reported in $5(10 \%)$ together with CIN in $3(6 \%)$ and CIS in $2(4 \%)$ participants. It is inconclusive in one participant (Table 3 ).

Table1. Socio-demographic characteristics of patients with suspected OSSN at Gondar University Hospital tertiary eye care and training center, Gondar, Northwest Ethiopia, 2016 $(\mathrm{n}=50)$

\begin{tabular}{|l|c|c|}
\hline Characteristics & Frequency (n) & Percent (\%) \\
\hline Age category (years) & \multicolumn{2}{|c|}{} \\
\hline $18-53$ & 7 & 86.0 \\
\hline $\mathbf{5 4}$ & & 14.0 \\
\hline Sex & 36 & 72.0 \\
\hline Male & 14 & 28.0 \\
\hline Female & & \\
\hline Occupation & 20 & 40.0 \\
\hline Farmer & 14 & 28.0 \\
\hline Civil servant & 7 & 14.0 \\
\hline Daily laborer & 6 & 12.0 \\
\hline Housewife & 2 & 4.0 \\
\hline Merchant & 1 & 2.0 \\
\hline Student & & \\
\hline
\end{tabular}


Table 2. Clinical features of OSSN at Gondar university hospital tertiary eye care and training center, Gondar, Northwest Ethiopia, $2016(\mathrm{n}=50)$

\begin{tabular}{|c|c|c|}
\hline Characteristics & Frequency (n) & Percent (\%) \\
\hline $\begin{array}{l}\text { Clinical appearance } \\
\text { Leukoplakic } \\
\text { Gelatinous } \\
\text { Papilliform } \\
\text { Fungating } \\
\text { Sessile \& strawberry like }\end{array}$ & $\begin{array}{l}34 \\
6 \\
5 \\
4 \\
1\end{array}$ & $\begin{array}{c}68.0 \\
12.0 \\
10.0 \\
8.0 \\
2.0\end{array}$ \\
\hline $\begin{array}{l}\text { Site of involvement } \\
\text { Bulbar conjunctiva } \\
\text { Limbus and bulbar conjunctiva } \\
\text { Limbus } \\
\text { Bulbar conjunctiva, Limbus and Cornea } \\
\text { Whole globe, orbit \& eyelids }\end{array}$ & $\begin{array}{c}14 \\
8 \\
3 \\
7 \\
16 \\
2\end{array}$ & $\begin{array}{c}28.0 \\
16.0 \\
6.0 \\
14.0 \\
32.0 \\
4.0\end{array}$ \\
\hline $\begin{array}{l}\text { Location } \\
\text { Nasal } \\
\text { Temporal } \\
\text { Nasal, temporal and superior } \\
\text { All quadrants of the globe } \\
\end{array}$ & $\begin{array}{c}37 \\
9 \\
1 \\
3\end{array}$ & $\begin{array}{l}74.0 \\
18.0 \\
2.0 \\
6.0\end{array}$ \\
\hline $\begin{array}{l}\text { Size in clock hours } \\
1-3 \\
4-6 \\
>6\end{array}$ & $\begin{array}{c}37 \\
9 \\
4\end{array}$ & $\begin{array}{c}74.0 \\
18.0 \\
8.0\end{array}$ \\
\hline $\begin{array}{l}\text { Pigmentation } \\
\text { No } \\
\text { Yes }\end{array}$ & $\begin{array}{c}47 \\
3\end{array}$ & $\begin{array}{c}94.0 \\
6.0\end{array}$ \\
\hline $\begin{array}{l}\text { Feeding vessels } \\
\text { Yes } \\
\text { No }\end{array}$ & $\begin{array}{c}42 \\
8\end{array}$ & $\begin{array}{l}84.0 \\
16.0\end{array}$ \\
\hline $\begin{array}{l}\text { Local metastasis } \\
\text { No } \\
\text { Yes }\end{array}$ & $\begin{array}{c}48 \\
2\end{array}$ & $\begin{array}{c}96.0 \\
4.0\end{array}$ \\
\hline $\begin{array}{l}\text { HIV positive } \\
\text { No } \\
\text { Yes }\end{array}$ & $\begin{array}{l}39 \\
11\end{array}$ & $\begin{array}{l}78.0 \\
22.0\end{array}$ \\
\hline $\begin{array}{l}\text { Smoking history } \\
\text { No } \\
\text { Yes }\end{array}$ & $\begin{array}{c}46 \\
4\end{array}$ & $\begin{array}{c}92.0 \\
8.0\end{array}$ \\
\hline $\begin{array}{l}\text { Globe trauma history } \\
\text { No } \\
\text { Yes }\end{array}$ & $\begin{array}{c}57 \\
3\end{array}$ & $\begin{array}{c}96.0 \\
6.0\end{array}$ \\
\hline $\begin{array}{l}\text { Previous recurrence } \\
\text { No } \\
\text { Yes }\end{array}$ & $\begin{array}{c}44 \\
6\end{array}$ & $\begin{array}{l}88.0 \\
12.0\end{array}$ \\
\hline
\end{tabular}

Table 3. Histological diagnosis of suspected OSSN in Gondar University Hospital tertiary eye care and training center, Gondar, Northwest Ethiopia, $2016(\mathrm{n}=50)$

\begin{tabular}{|l|c|c|}
\hline \multicolumn{1}{|c|}{ Histological diagnosis } & Frequency (n) & Percent (\%) \\
\hline CIN & 6 & 12.0 \\
\hline CIS & 18 & 36.0 \\
\hline SCC & 18 & 36.0 \\
\hline Pterygium and CIN & 3 & 6.0 \\
\hline Pterygium and CIS & 2 & 4.0 \\
\hline Papilloma & 1 & 2.0 \\
\hline Pinguecula & 1 & 2.0 \\
\hline Inconclusive & 1 & 2.0 \\
\hline
\end{tabular}

\section{Discussion}

This study described the clinical and histopathological characteristics of ocular surface squamous neoplasia among a series of patients presented at a tertiary eye care center in Ethiopia.

The mean age of participants in this study was 41.26 years which is comparable with previous reports from Sub Saharan Africa [2-4]. The majority of the participants were males which is in agreement with worldwide incidence of OSSN where males are mainly affected. However, it is unlike many other reports from Sub-Saharan Africa where both females and males are equally affected, or females are predominantly affected by OSSN. This difference could be due to the difference of our study participants which is a single hospital-based population unlike other African studies which are multi center studies with large sample size [5,6]. In contrast, it is similar to reports from temperate climates where males are predominantly affected but in our study the males affected are relatively younger or middle aged whereas those from temperate climates are old aged males [3].

The majority of the participants affected by OSSN in our study are farmers and males which are presumed to be prone for outdoor activities and exposure to UV solar radiation. This is in agreement with previous reports where exposure to UV solar radiation is attributed as one of the major risk factors for the development of OSSN $[8,17]$.

Among the clinical presentations the commonest is leukoplakic appearance in the majority of the participants which is similar to a report from Africa but unlike the report from Asia where the commonest presentation was gelatinous appearance $[18,19]$. Feeder vessels and pigmentation of OSSN lesions were also among the predominant clinical findings. Though it is important that these clinical presentations are commonly observed in OSSN, it is also important to note that they could also be the clinical presentations of benign conjunctival lesions as well. This has been reported by the study conducted in Kenya where histopathological findings revealed a high degree of overlap between benign and malignant conjunctival lesions [19].

The prevalence of HIV positivity in our study participants is unlike the reports from other Sub Saharan African countries where a high number of patients with OSSN were found to be positive for HIV infection. According to the report by S Gichuhi from Kenya the prevalence of HIV infection in patients with OSSN was $72 \%$ and similarly a report from Malawi showed that OSSN to be the first apparent manifestation of HIV infection in $72 \%$ of their patients $[6,19]$. In our study participants only $22 \%$ of them were positive for HIV infection similar to a report from India [20]. This may be explained by other confounding factors like UV solar radiation exposure, outdoor activities and HPV infection which are still considered to be the predisposing factors for the development of OSSN $[9,17]$.

The commonest location of the OSSN lesions in this study is the nasal side $(74 \%)$ of the globe similar to most previous reports that ranges between $61 \%$ to $78 \%[6,18]$. This has been explained by incident temporal light being focused nasally with a 20 -fold magnification on intensity affecting the nasal side of the conjunctiva according to Coroneo M [21].

Pterygium was an associated clinical and histopathological finding in $(10 \%)$ of the participants. Similarly, it has also been reported from Australia where $9.8 \%$ of patients with OSSN had associated pterygium $[3,22,23]$. In addition to this a report from Bascom Palmer showed the presence of an associated pterygium in $1.7 \%$ of the OSSN lesions [24]. This associated presence of pterygium with OSSN could be explained by the similarity of the pathophysiology of the two lesions with similar predisposing factors like solar Ultraviolet Radiation, p53 gene mutation and Human Pailoma Virus infection $[9,17,24]$. This may also emphasize the importance of subjecting clinically suspicious fibrovascular growth for histopathological examination.

Almost all of the lesions with large size (4-12 clock hours) turned out to be invasive SCC complementing to the reports from subSaharan countries which showed that being large in size is significantly associated with invasive SCC $[6,25]$.

Among the participants enrolled in the study with clinical suspicion of OSSN, 47 (96\%) were found to have histopathological 
Gebremariam TH (2018) Clinical and histopathological characteristics of ocular surface squamous neoplasia: Evidence from a tertiary eye care center, northwest Ethiopia

proven OSSN. This could explain the role of histopathological examination in confirming the diagnosis of malignant lesions which could have overlapping clinical features with benign lesions so that appropriate management approach could be practiced. The high yield of this histopathology evaluation also supports the role of stereoscopic evaluation of the lesions with the slit lamp in clinically suspicious malignant lesions [26].

The strength of this study is its being a prospective one and the first report on the subject matter in Ethiopia. However, it has its own limitations because of its small sample size and absence of control group.

\section{Conclusions}

Despite the age of the patient and status of HIV infection it is good to subject suspected OSSN lesions for histopathological examination. Most of the patients were farmers and the role of other risk factors need to be considered and large-scale studies are recommended in Ethiopia and other African countries in the future.

\section{Reference}

1. Lee GA, Hirst LW (1995) Ocular surface squamous neoplasia. Surv Ophthalmol 39: 429-450. [Crossref]

2. Sun EC, Fears TR, Goedert JJ (1997) Epidemiology of squamous cell conjunctival cancer. Cancer Epidemiol Biomarkers Prev 6: 73-77. [Crossref]

3. Lee GA, Hirst LW (1992) Incidence of ocular surface epithelial dysplasia in metropolitan Brisbane: a 10-year survey. Arch Ophthalmol 110: 525-527. [Crossref]

4. Templeton AC (1967) Tumors of the eye and adnexa in Africans of Uganda. Cancer 20: 1689-1698. [Crossref]

5. Furahini G, Lewallen S (2010) Epidemiology and management of ocular surface squamous neoplasia in Tanzania. Ophthalmic Epidemiol 17: 171-176. [Crossref]

6. Tiong T, Borooah S, Msosa J, Dean W, Smith C, et al. (2013) Clinicopathologica review of ocular surface squamous neoplasia in Malawi. Br J Ophthalmol 87: 961-964. [Crossref]

7. Gichuhi S, Sagoo MS, Weiss HA, Burton MJ (2013) Epidemiology of ocular surface squamous neoplasia in Africa. Trop Med Int Health 18: 1424-1443. [Crossref]

8. Waddell K, Kwehangana J, Johnston WT, Lucas S, Newton R (2010) A case-contro study of ocular surface squamous neoplasia (OSSN) in Uganda. Int J Cancer 127: 427432. [Crossref]

9. Scott IU, Karp CL, Nuovo GJ (2002) Human papillomavirus 16 and 18 expression in conjunctival intraepithelial neoplasia. Ophthalmology 109: 542-547. [Crossref]

10. Yu JJ, Fu P, Pink JJ, Dawson D, Wasman J, et al. (2010) HPV infection and EGFR activation/alteration in HIV-infected East African patients with conjunctival carcinoma. PLoS One 5: e10477. [Crossref]
11. Iliff WJ, Marback R, Green WR (1975) Invasive squamous cell carcinoma of the conjunctiva. Arch Ophthalmol 93: 119-122. [Crossref]

12. Adesina A, Chumba D, Nelson AM, Orem J, Roberts DJ, et al. (2013) Improvement of pathology in sub-Saharan Africa. Lancet Oncol 14: e152-157. [Crossref]

13. Rambau PF (2011) Pathology practice in a resource-poor setting: Mwanza, Tanzania. Arch Pathol Lab Med 135: 191-193. [Crossref]

14. Assegid A (2001) Pattern of ophthalmic lesions at two histopathology centres in Ethiopia. East Afr Med J 78: 250-254. [Crossref]

15. Commision F (2008) Democratic Republic of Ethiopia. Population Census Summary and Stastical Report of the 2007 population and housing census. United Nations population fund.

16. World Medical Association (2013) World medical association declaration of Helsinki Ethical principles for medical research involving human subjects. JAMA 310: 2191 2194. [Crossref]

17. Newton R, Reeves G, Beral V, Ferlay J, Parkin D (1996) Effect of ambient solar ultraviolet radiation on incidence of squamous-cell carcinoma of the eye. Lancet 347 : 1450-1451. [Crossref]

18. Gichuhi S, Macharia E, Kabiru J, Zindamoyen AM, Rono H, et al. (2015) Clinical presentation of ocular surface squamous neoplasia in Kenya. JAMA Ophthalmol 133: 1305-1313. [Crossref]

19. Kim BH, Kim MK, Wee WR, Oh JY (2013) Clinical and pathological characteristics of ocular surface squamous neoplasia in an Asian population. Graefes Arch Clin Exp Ophthalmol 251: 2569-2573. [Crossref]

20. Pradeep TG, Gangasagara SB, Subbaramaiah GB, Suresh MB, Gangashettappa N, et al. (2012) Prevalence of undiagnosed HIV infection in patients with ocular surface squamous neoplasia in a tertiary center in Karnataka, South India. Cornea 31: 12821284. [Crossref]

21. Coroneo M (2011) Ultraviolet radiation and the anterior eye. Eye Contact Lens 37: 214-224. [Crossref]

22. Hirst LW, Axelsen RA, Schwab I (2009) Pterygium and associated ocular surface squamous neoplasia. Arch Ophthalmol 127: 31. [Crossref]

23. Yeung SN, Kim P, Lichtinger A, Amiran MD, Cote E, et al. (2011) Incidence of ocular surface squamous neoplasia in pterygium specimens: an 8-year survey. $\mathrm{Br} J$ Ophthalmol 95: 592. [Crossref]

24. Kao AA, Galor A, Karp CL, Abdelaziz A, Feuer WJ, et al. (2012) Clinicopathologic correlation of ocular surface squamous neoplasms at Bascom Palmer Eye Institute: 2001 to 2010. Ophthalmology 119: 1773-1776. [Crossref]

25. Makupa II, Swai B, Makupa WU, White VA, Lewallen S (2011) Clinical factors associated with malignancy and HIV status in patients with ocular surface squamous neoplasia at Kilimanjaro Christian Medical Centre, Tanzania. Br J Ophthalmol 96: 482484. [Crossref]

26. Katsekera E, Tanyanyiwa L, Chikwasha V, Masanganise R (2014) Screening for ocular surface squamous neoplasia by slit lamp assisted visual inspection following a short of mild topical steroid test qualities. S Afr Optom 73: 16-20.

Copyright: (C2018 Gebremariam TH. This is an open-access article distributed under the terms of the Creative Commons Attribution License, which permits unrestricted use, distribution, and reproduction in any medium, provided the original author and source are credited. 